\title{
ILCEA
}

Revue de l'Institut des langues et cultures

d'Europe, Amérique, Afrique, Asie et Australie

$40 \mid 2020$

English for Specific Purposes (ESP) and the Underlying Dynamics of Power, Empowerment and Disempowerment

\section{English in the Contact Zone: Change and Stability}

L'anglais en zones de contact: changements et stabilité

\section{Sue Starfield}

\section{(2) OpenEdition}

\section{Journals}

Electronic version

URL: http://journals.openedition.org/ilcea/10451

DOI: 10.4000/ilcea.10451

ISSN: 2101-0609

\section{Publisher}

UGA Éditions/Université Grenoble Alpes

\section{Printed version}

ISBN: 978-2-37747-204-8

ISSN: 1639-6073

\section{Electronic reference}

Sue Starfield, « English in the Contact Zone: Change and Stability », ILCEA [Online], 40 | 2020, Online since 04 June 2020, connection on 05 September 2020. URL : http://journals.openedition.org/ilcea/ 10451 ; DOI : https://doi.org/10.4000/ilcea.10451

This text was automatically generated on 5 September 2020

(c) ILCEA 


\title{
English in the Contact Zone: Change and Stability
}

L'anglais en zones de contact : changements et stabilité

\author{
Sue Starfield
}

English is closely tied to processes of globalization: a language of threat, desire, destruction and opportunity. [...] English is a translocal language, a language of fluidity and

fixity that moves across, while becoming embedded in, the materiality of localities and social relations. English is bound up with transcultural flows, a language of imagined communities and refashioning identities.

(Pennycook, 2007: 5-6)

1 Alastair Pennycook's words speak directly to many of the concerns of the papers in this special issue of ILCEA on the theme of English for specialised purposes and the underlying dynamics of power, empowerment and disempowerment. They draw our attention to English's unique ability in the contemporary moment to function as a floating signifier-a highly mobile language in Blommaert's terms which attaches users to it and to which users attach in a multitude of contexts. The power of English resides to a great extent in this protean ability to appropriate and be appropriated, to grant access and to deny it and to privilege some identities at the expense of others. Individual and collective purposes for learning/using English under conditions of superdiversity as described by Blommaert (2010) are subject to intense, sometimes contradictory pulls, these may be multiple and contingent but can also be highly specific.

2 The mobility of English-its transculturality-calls into question notions of homogenous discourse communities/disciplines into which 'insiders' can simply 'induct' outsiders through explaining the 'rules'. In today's superdiverse contexts there will always be struggles over power, meaning and ownership in the 'contact zones'- 
Mary Louise Pratt's term for the "social spaces where cultures meet, clash, and grapple with each other, often in contexts of highly asymmetrical relations of power, such as colonialism, slavery, or their aftermaths as they are lived out in many parts of the world today". She identifies many of the challenges we face daily, "miscomprehension, incomprehension, [...], absolute heterogeneity of meaning-[as] some of the perils of writing in the contact zone" (1991: 34).

3 The multicultural, multilingual authors of this special issue all inhabit today's contact zones where past and present power relations are simultaneously produced and reproduced. ESP, as its history is laid out for us by several of the authors, in particular, Nadežda Stojković, carries with it its origins in its 'civilising' mission and the imperialistic ambitions of some. At the same time, for many, English is the language of opportunity and even the language of human rights as we see protestors across the globe getting their message out in English.

4 As Philippe Millot shows us, 'proficiency' in English is greater than the sum of its parts; fundamentally shaping the identities and, dare I say, the bodies of those who are deemed competent professionals. English as a Lingua Franca (ELF) and Business English as a Lingua Franca (BELF) are, in Bourdieu's (1982) terms, the 'legitimate' languages of the contact zone, directly imbricating desired and desirable identity. This paper and others address the ongoing question of the ownership of English raised a number of years ago by Henry Widdowson (1994). Bakhtin's centrifugal forces for change seem to have the upper hand as BELF usage among business professionals in France appears “ stablised for now" (Schryer, 1994: 108).

On ther hand, dictionaries, as Olga Menagarishvili argues, play a centripetal role in stabilising ownership, whether of English or another language, through the power of inclusion and exclusion. As Bakhtin reminds us, however, "it is not, after all, out of a dictionary that the speaker gets his [sic] words!" (1981: 294). For, as Miguel Angel Campos-Prados and Isabel Balteiro's paper reveals, the forces for change, often operating 'from below' can disrupt existing power relations, using new modes such as social media to flow across contact zones and challenge norms and convention as users of English exercise agency in creating dispersed local centres of power allowing a new, heteroglossic lexicon to emerge, continuing the struggle for legitimacy.

6 Although it has been argued that digital technologies have led to rearrangements of power towards more democratic forms (Kress, 2010), Ruth Breeze's study of a digital platform for dispute resolution suggests that communication across space and time is not necessarily exempt from the instantiation of discursive inequality. The specialised purposes of digital communication and their not always predictable outcomes certainly demand greater attention from our field.

7 The Law and Literature movement embodies the arts of the contact zone-challenging traditional disciplinary boundaries. Malcolm Harvey intriguingly takes us to the world of ancient Greece where power is closely contested in a world surprisingly reminiscent of our own; he challenges us to recognise the specialised purposes to which engagement with literature can be put and to recognise that the study of language is always about more than language.

8 Michel Van der Yeught rightly identifies the constitutive power that resides in specialised communities; I take from his interrogation the need to relentlessly question, to not fall prey to the illusions of the stablised norm but to adopt Pennycook's call for "a restive problematization of the given" (2001: 171). A Bakhtinian perspective, 
however, allows us to see how "as long as language is alive and developing", every utterance simultaneously "participates in the "unitary language"' (centripetal forces for stability) and is stratified by social and historical heteroglossia (centrifugal forces for change) (1981: 272).

When considering matters of power and language, of the nature of specialisation, it remains essential to examine how communities are constituted and reproduce themselves: in other words, who counts as a legitimate entrant? We should be mindful of Loic Wacquant's injunction that

[...] linguistic relations are always relations of power (rapports de force) and, consequently, cannot be elucidated within the compass of linguistic analysis alone. Even the simplest linguistic exchange brings into play a complex and ramifying web of historical power relations between the speaker, endowed with a specific social authority and an audience, which recognises this authority to varying degrees, as well as between the groups to which they respectively belong. (Wacquant, cited by Jenkins, 2002: 154)

As researchers and practitioners, we need to be alert to the flow of language in the contact zone; the subtle shifts of power, the resurgence of conflicts perhaps thought over, the emergence of new desires, new struggles and new communities that form and vanish and reshape identities in the process. However, we should not lose sight of the promise that Pratt holds out: "Along with rage, incomprehension, and pain, there were exhilarating moments of wonder and revelation, mutual understanding, and new wisdom-the joys of the contact zone." (Pratt, 1991: 39)

11 I thank Shaeda Isani and Séverine Wozniak for this opportunity and congratulate them on conceptualising this project and bringing it to fruition.

\section{A Personal Coda}

Shaeda Isani and Séverine Wozniak, in their foreword, ask me to "cast my 'Australian' eye" on the work collected in this volume. I need to confess that this 'eye' is only partially Australian. I feel I must challenge this positioning and out myself as a citizen of the contact zone.

13 Although 20 years have passed, I still feel a fairly recent Australian. My initial work in this field took place in my birth country, South Africa, and had its origins in the overwhelming inequality reproduced daily in that country and at the previously whites-only university where I worked. My initial work setting up academic programs to support black students entering the university from apartheid schooling explicitly challenged prevailing views on ESP and EAP and argued for an integration of language and disciplinary content (Starfield, 1990).

Prior to this, I spent several years in France, completing my master's in applied linguistics and a DEA and where I was first introduced to the idea of languages for specific purposes by an inspirational professor, Mme Sophie Moirand from Université Sorbonne Nouvelle - Paris 3. 


\section{BIBLIOGRAPHY}

BAKHTIN Mikhail M. (1981), The Dialogic Imagination, Austin, TX: University of Texas Press.

BlOMMAERT Jan (2010), The Sociolinguistics of Globalization, Cambridge: Cambridge University Press.

BOURDIEU Pierre (1982), Ce que parler veut dire, Paris: Fayard.

KRESS Gunter (2010), Multimodality: A Social Semiotic Approach to Contemporary Communication, London and New York: Routledge.

JENKINS Richard (2002), Pierre Bourdieu, London and New York: Routledge.

PENNYCOOK Alastair (2001), Critical Applied Linguistics: A Critical Introduction, Mahwah, NJ: Lawrence Erlbaum.

PENNYCOOK Alastair (2007), Global Englishes and Transcultural Flows, London and New York:

Routledge.

PRATT Mary Louise (1991), "Arts of the Contact Zone”, Profession, 33-40.

SCHRYER Catherine (1994), “The Lab vs. the Clinic: Sites of Competing Genres”, A. Freedman \&

P. Medway (eds), Genre and the New Rhetoric, London: Taylor \& Francis, 105-24.

STARFIELD Sue (1990), “Science and Language: A New Look at Some Old Issues”, South African

Journal of Higher Education, 4, 84-9.

WIDDowson Henry G. (1994), “The Ownership of English”, TESOL Quarterly, 28, 377-89.

\section{AUTHOR}

\section{SUE STARFIELD}

University of New South Wales (Australia).

Sue Starfield is Professor in the School of Education, University of New South Wales (Australia). Her research covers tertiary academic literacies, doctoral writing, writing for publication, postgraduate pedagogy, ESP, identity in academic writing and access and equity in higher education.

A widely published author, she is well-known to ESP scholars through The Handbook of English for Specific Purposes (2013) co-edited with Brian Paltridge. Since then, she has also co-edited Ethnographic Perspectives on Academic Writing (2016) and, more recently, Palgrave Handbook of Applied Linguistics Research Methodology (2019).

She also edits two book series with Routledge in the field of ESP: Introductions to English for Specific Purposes and Research in English for Specific Purposes.

s.starfield@unsw.edu.au 